\title{
Performance and Carcass Characteristics of West African Dwarf Goats Fed Cassava Peel Meal Partially Replaced with Sugarcane Peel Meal
}

\author{
Peter Noah Gboshe*, Bassey Asuquo Ukorebi \\ Department of Animal Science, Faculty of Agriculture and Forestry, Obubra Campus, Cross River University of Technology, Calabar, Cross \\ River State, Nigeria
}

Email address:

petergboshe72@gmail.com (P. N. Gboshe)

${ }^{*}$ Corresponding author

\section{To cite this article:}

Peter Noah Gboshe, Bassey Asuquo Ukorebi. Performance and Carcass Characteristics of West African Dwarf Goats Fed Cassava Peel Meal Partially Replaced with Sugarcane Peel Meal. Animal and Veterinary Sciences. Special Issue: Current Topics in Reproductive Physiology and Assisted Reproductive Technologies in Farm and Wildlife Animals. Vol. 8, No. 1, 2020, pp. 36-40. doi: 10.11648/j.avs.20200801.15

Received: November 13, 2019; Accepted: January 28, 2020; Published: April 1, 2020

\begin{abstract}
A 90-day feeding trial involving 20, 4-5-month old West African Dwarf bucks was carried out to evaluate the performance, carcass and its by-products characteristics expressed as percentage of their live weight in a completely randomized design. The animals were fed cassava peel meal partially replaced by sugarcane peel meal at dietary levels of 100 , $75,50,25,0$ and $0,25,50,75$, and $100 \%$ for $\mathrm{T} 1, \mathrm{~T} 2 \mathrm{~T} 3 \mathrm{~T} 4$, respectively. The parameters measured were performance traits, carcass and by-products characteristics. From the parameters evaluated, feed intake (280.74-349.77 g/day), daily body weight gain $(32.22-45.88 \mathrm{~g} / \mathrm{kg})$, total weight gain $(3.17-4.13 \mathrm{~kg})$, final body weight $(11.38-12.33 \mathrm{~kg})$, daily water intake $(665.55-$ $838.55 \mathrm{ml}$ ), and feed conversion ratio (7.63-8.83) were significantly affected. Carcass characteristics, loin, and back expressed as percentage live weight were significantly affected. While dressing percentage, live weight, carcass weight, rib, shoulder neck, thigh $\%$ and the by-products parameters evaluated which were also expressed as percentage live weight were not significantly affected. The non-enlargement of other visceral organs such as lungs, liver, heart, kidney, spleen, testes, full gut and empty gut in this study is an indication that, the peel meals does not have any negative effect on the development of the whole cuts. It is therefore, safe for goats' feeding and could be incorporated as feeds ingredients in their feeding which can help, not only to reduce cost of production but also to increase meat production.
\end{abstract}

Keywords: Agro-industrial by-Products, Growth Rate, Goats, Organs, Cassava Peel, Sugarcane Peel

\section{Introduction}

In considering the need to step up the production of various livestock to attempt to meet the animal protein requirement by human, one would arrive at the conclusion that, enhanced production of goats, holds the key to bridging the gap between this animal protein requirement and supply [1]. Goat is capable of performing this fit because of its peculiar endowments which has production advantages over most of other livestock. Goats can survive in large numbers under extensive, under developed, semi-arid, overgrazed, denuded sites and particularly on mountain slopes [2]. This goats can however, be improved through adequate management. Nutrition has been identified as a key factor to the success of animal production in Nigeria. This is because the northern part where over $80 \%$ of the ruminants are found is faced with severe feed scarcity during the dry season and available herbage is of low quality. This problem seems to be compounded by the fact that, we cannot afford to feed whole grains and tubers to animals in this country because of the high level of need by man for these produce.

The lack of improvement in crop production and the competition between humans and animals for available grains and tubers make nutritional requirement at reasonable cost, difficult to achieve since a viable livestock industry is dependent on agricultural products.

Consequently, animals are unable to meet both their protein and energy requirements, therefore, there is, a very 
negative effect such as; marked weight loss, lowered disease resistance, death, seasonal anoestrus, reduced fertility and slow growth rate that is usually observed on our animals which needed urgent attention [3].

Given the above scenario, it would not be out of place therefore to search for inexpensive, readily available and nutritionally adequate feed materials especially those that are not in direct use by humans.

The possible source of cheap and available source are the cassava peel meal (CPM) and the sugarcane peel meal (SCPM). CPM is cheap and readily available by-product of cassava processing and contain 5\% crude protein, $5.8 \%$ fat, $9.5 \%$ crude fibre, $7.2 \%$ ash and $2036 \mathrm{kcal}$ Metabolizable energy [4]. While SCPM is one of such usable by-product crop residues used as ruminants feeds because of its nutritional components [5]. Sa'adullah [6] reported that, ruminants responded positively when fed diets based on crop residues and sugar-rich agro industrial by-products supplemented with small quantities of by-pass protein.

Sugarcane peels is available during the dry season in Northern Nigeria and in the study area and the use of sugarcane peels as feedstuff will help in reducing the problem of feed shortage in Nigeria. According to Ayoade et al. [7] exploitation of cheap feed resources for animal production would lower the market price of animals and their products in Nigeria. It was therefore the aim of the study to evaluate the performance and carcass characteristics of West African Dwarf goats fed cassava peel meal partially replaced by sugarcane peel meal.

\section{Materials and methods}

\subsection{Study Area}

The experiment was carried out at the Teaching and Research Farms of Faculty of Agriculture and Forestry, Cross River state University of Technology (CRUTECH) Obubra,
Cross River state, Nigeria. This study area is located between longitude $8^{\circ}-9^{\circ} \mathrm{E}$ and Latitude $6^{\circ}-7^{\circ} \mathrm{N}$ of the equator. The mean annual rainfall of the area ranges from 500 to 1070 $\mathrm{mm}$, with a warm weather and ambient temperature of about $20^{\circ} \mathrm{C}-30^{\circ} \mathrm{C}$. Obubra is located along the banks of the Cross River in the Southern Guinea Agro-Ecological Zone of Nigeria. It is about $159 \mathrm{~km}$ from Calabar, the state capital of Cross River State of Nigeria.

\subsection{Processing of the Peel Meals and Experimental Diets}

The cassava peel (CP) and sugarcane peel (SCP) were collected within the villages around Faculty of Agriculture and Forestry, Cross River University of Technology, Calabar, Nigeria. These ingredients were sun dried intensively on a concrete slap separately for a period of 3 days and finally SCP was milled with a forage chopping machine while the $\mathrm{CP}$ was roughly milled using a hammer mill to produce the peel meals which were then incorporated in their various levels in the experimental diets and samples of each subjected to proximate analysis according to AOAC [8]. The proximate composition of the test ingredients is summarized in Table 1.

Table 1. Proximate composition of the test ingredients.

\begin{tabular}{llllll}
\hline Ingredients & $\begin{array}{l}\text { Crude } \\
\text { protein }\end{array}$ & $\begin{array}{l}\text { Ether } \\
\text { extract }\end{array}$ & $\begin{array}{l}\text { Crude } \\
\text { fibre }\end{array}$ & Ash & NFE \\
\hline Cassava peel & 5.00 & 5.80 & 9.50 & 7.20 & 72.50 \\
Sugarcane peel & 6.51 & 4.47 & 25.34 & 9.83 & 53.85 \\
\hline
\end{tabular}

$\mathrm{NFE}=$ Nitrogen free extract

Based on the result of the chemical analysis, four diets were formulated to contain $0,25,50,75$ and $100 \%$ of sugarcane meal and $100,75,50$ and $0 \%$ of cassava peel meal. The treatment diets varies slightly in their energetic and nitrogenous content Table 2 .

Table 2. Composition of the experimental diets.

\begin{tabular}{lllll}
\hline & \multicolumn{2}{l}{ Dietary levels of the peel meals, \% } & & T4 75 SCPM 25 CPM \\
\hline Ingredients\% & T1 0 SCPM 100 CPM & T2 25 SCPM 75 CPM & T3 50 SCPM 50 CPM & 26.25 \\
\hline Sugarcane peel meal & 0.00 & 8.75 & 17.50 & 8.75 \\
Cassava peel meal & 35.00 & 26.25 & 17.50 & 20.00 \\
Rice offal & 20.00 & 20.00 & 20.00 & 20.00 \\
Palm kernel cake & 20.00 & 20.00 & 20.00 & 20.00 \\
Ground nut haulm & 20.00 & 20.00 & 20.00 & 2.00 \\
Salt & 2.00 & 2.00 & 2.00 & 3.00 \\
Bone meal & 3.00 & 3.00 & 3.00 & 100.00 \\
Total & 100.00 & 100.00 & 100.00 & 10.01 \\
Calculated values & & & 2.00 \\
Crude protein\% & 9.61 & 9.72 & 9.88 & 2.05 \\
Crude Fibre\% & 18.90 & 20.28 & 21.66 & 207.66 \\
ME (Kcal/kg) & 2051.61 & 2059.63 & 2067.65 & \\
\hline
\end{tabular}

$\mathrm{SCPM}=$ Sugarcane peel meal, $\mathrm{CPM}=$ Cassava peel meal, $\mathrm{ME}=$ Metabolizable energy

\subsection{Experimental Goats}

A total of 20 West African Dwarf buck goats of about 6-7 months, with initial weight of $8.35 \mathrm{~kg}$ were divided into 4 groups of 5 goats each and randomly assigned to the four treatment diets in a Completely Randomized Design (CRD) experiment. Each treatment group was further sub-divided into 5 replicates with an animal serving as a replicate. They were kept in a $90(\mathrm{~L}) \times 80(\mathrm{~W}) \times 65(\mathrm{H}) \mathrm{cm}^{3}$ compartment. An adjustment period of a week was allowed for the animals 
before data collection commences.

The animals were weighed at the beginning of the experiment and at weekly intervals thereafter and divided by 7 to obtain the daily weight. Weighed quantity of Feed and water were offered daily and the leftover was weighed to determine their intake. Other routine goat management practices were maintained. The feeding trial lasted 90 days. Total feed intake, water intake, and weight were determined at the end of the study. Feed conversion ratio (FCR) was also determined by calculation of the ratio (Feed: Gain).

\subsection{Carcass Evaluation}

At the end of the $90^{\text {th }}$ day, two (2) bucks per treatment giving a total of eight (8) bucks were deprived of feed but not water for a day, slaughtered and eviscerated for organ weight determination and other carcass indices evaluations.

\subsection{Data Analysis}

The data obtained were subjected to analysis of variance (ANOVA) [9] and the means were compared using least significant difference (LSD) of the statistical software package.

\section{Results}

The summary of the effects of inclusion levels of the peel meals on the performance parameters of the Goats is as presented in Table 3 . The analysis of variance revealed a significant $(p<0.05)$ difference between treatment groups in all the parameters measured. It was also observed that all the performance traits measured in T1 with $100 \%$ cassava peel meal was significantly $(\mathrm{p}<0.05)$ difference from the other treatments.

Table 3. Performance of West African Dwarf Goats fed varying levels of cassava peels partially placed by sugarcane peels.

\begin{tabular}{|c|c|c|c|c|c|}
\hline \multicolumn{6}{|l|}{ Dietary levels of the peel meals, $\%$} \\
\hline Ingredients\% & TI 0 SCPM 100 CPM & T2 25 SCPM 75 CPM & T3 50SCPM 50 CPM & T475 SCPM 25 CPM & SEM \\
\hline Average Final body weight (kg) & $12.33^{\mathrm{a}}$ & $11.65^{\mathrm{c}}$ & $12.20^{\mathrm{b}}$ & $11.38^{\mathrm{d}}$ & 0.00 \\
\hline Total weight gain (kg) & $13^{\mathrm{a}}$ & 2. $90^{\mathrm{d}}$ & $3.83^{\mathrm{b}}$ & $3.17^{\mathrm{c}}$ & 0.03 \\
\hline Average Daily feed intake (g/day) & $349.77^{\mathrm{a}}$ & $280.74^{\mathrm{d}}$ & $338.19^{\mathrm{b}}$ & $310.94^{\mathrm{c}}$ & 0.00 \\
\hline Average daily weight gain $(\mathrm{g} / \mathrm{kg})$ & $45.88^{\mathrm{a}}$ & 32. $22^{\mathrm{d}}$ & $42.56^{\mathrm{b}}$ & $35.22^{\mathrm{c}}$ & 0.00 \\
\hline Average Water intake (ml) & $838.55^{\mathrm{a}}$ & $782.42^{\mathrm{b}}$ & $752.09^{c}$ & $665.59^{d}$ & 0.00 \\
\hline Feed: Gain & $7.63^{\mathrm{d}}$ & $8.71^{\mathrm{b}}$ & $7.95^{\mathrm{c}}$ & $8.83^{\mathrm{a}}$ & 0.00 \\
\hline
\end{tabular}

$\mathrm{a}, \mathrm{b}, \mathrm{c}, \mathrm{d}=$ Means in the same row with different super scripts are significantly different $(\mathrm{P}<0.05)$, SEM standard error of mean, $\mathrm{SCPM}=\mathrm{Sugarcane}$ peel meal, $\mathrm{CPM}=$ Cassava peel meal.

The summary of the effects of inclusion levels of the peel meals on the carcass characteristics of the Goats is presented in Table 4. The analysis of variance of the percentage loin and back differed $(\mathrm{p}<0.05)$ significantly with the levels of peels inclusion, while other carcass parameters such as; the carcass weight, dressing percentage, ribs, shoulder neck and thighs expressed as percentage live weight were not significantly ( $\mathrm{p}>0.05)$ affected between the treatment groups.

Table 4. Carcass Characteristics of West African Dwarf Goats fed different levels of cassava peels partially placed with sugarcane peels.

\begin{tabular}{|c|c|c|c|c|c|}
\hline \multicolumn{6}{|c|}{ Dietary levels of the peel meals, \% } \\
\hline Parameters & T10 SCPM 100 CPM & T2 25 SCPM 75 CPM & T3 50 SCPM 50 CPM & T4 75 SCPM 25 CPM & SEM \\
\hline Live weight (kg) & 12.60 & 10.08 & 11.48 & 10.80 & 2.62 \\
\hline Carcass weight $(\mathrm{kg})$ & 5.85 & 4.33 & 5.55 & 4.85 & 1.57 \\
\hline Dressing percentage $\%$ & 46.43 & 42.94 & 46.35 & 44.69 & 3.93 \\
\hline Ribs\% & 6.70 & 5.71 & 6.25 & 6.20 & 1.11 \\
\hline Loin $\%$ & $8.53^{\mathrm{ab}}$ & $8.19^{\mathrm{b}}$ & $8.77^{\mathrm{c}}$ & $8.34^{\mathrm{d}}$ & 0.55 \\
\hline Back\% & 4. $77^{\mathrm{a}}$ & $3.38^{\mathrm{b}}$ & $5.02^{\mathrm{a}}$ & 4. $37^{\mathrm{ab}}$ & 0.65 \\
\hline Neck\% & 5.36 & 4.95 & 5.22 & 5.05 & 0.91 \\
\hline Thighs $\%$ & 11.71 & 11.42 & 11.90 & 11.98 & 1.06 \\
\hline
\end{tabular}

$\mathrm{a}, \mathrm{b}, \mathrm{c}, \mathrm{d}=\mathrm{Means}$ in the same row with different super scripts are significantly different $(\mathrm{P}<0.05)$, SEM standard error of mean, $\mathrm{SCPM}=\mathrm{Sugarcane}$ peel meal, $\mathrm{CPM}=$ Cassava peel meal

The summary of the effects of inclusion levels of the peel meals on the carcass by-products and visceral organs of the experimental Goats is as presented in Table 5. The analysis of variance revealed no significant $(\mathrm{p}>0.05)$ difference between treatment groups regardless of the by-products characteristics evaluated.

Table 5. Carcass by-products of West African Dwarf Goats fed different levels of cassava peels partially placed by sugarcane peels.

\begin{tabular}{llllll}
\hline Dietary levels of the peel meals, \% & & & \\
\hline Parameters\% & T10 SCPM 100 CPM & T2 25 SCPM 75 CPM & T3 50 SCPM 50 CPM & T4 75 SCPM 25 CPM & SEM \\
\hline Head & 8.54 & 8.69 & 8.56 & 8.57 & 0.56 \\
Legs & 2.98 & 2.99 & 2.72 & 2.55 & 0.47 \\
Heart & 1.18 & 1.20 & 1.17 & 1.20 & 0.19 \\
Lung & 1.87 & 1.83 & 1.63 & 1.57 & 0.42 \\
\hline
\end{tabular}




\begin{tabular}{llllll}
\hline \multicolumn{2}{l}{ Dietary levels of the peel meals, \% } & & & \\
\hline Parameters\% & T10 SCPM 100 CPM & T2 25 SCPM 75 CPM & T3 50 SCPM 50 CPM & T4 75 SCPM 25 CPM & SEM \\
\hline Liver & 1.76 & 1.49 & 1.46 & 1.62 & 0.16 \\
Kidney & 0.70 & 0.59 & 0.67 & 0.17 & 0.18 \\
Spleen & 0.19 & 0.17 & 0.18 & 1.62 & 0.05 \\
Testes & 1.79 & 1.48 & 1.46 & 19.79 & 0.49 \\
Full gut & 19.84 & 4.85 & 19.41 & 4.43 & 2.15 \\
Empty gut & 3.98 & 4.72 & 4.18 & 4.85 & 0.59 \\
Skin & 4.62 & 4.95 & 4.81 & 0.65 \\
\hline
\end{tabular}

$\mathrm{a}, \mathrm{b}, \mathrm{c}, \mathrm{d}=$ Means in the same row with different superscripts are significantly different $(\mathrm{P}<0.05)$,

SEM standard error of mean, SCPM= Sugarcane peel meal, CPM= Cassava peel meal

\section{Discussion}

The values for average daily feed intake (ADFI) of 280.74-349.77 $\mathrm{g} /$ day reported in this study were lower than $710.8 \mathrm{~g} /$ day reported by Ramli et al. [10] for goats fed fermented sugarcane bagasse feed and $723.1 \mathrm{~g}$ /day reported by Saleh [11] for 30\% sugarcane peels diet fed to Yankasa sheep. The variation in the above mentioned (ADFI) recorded by different authors could be due to factors like size of the animal and variation in level of nutrients composition in feeds. This agreed with the assertion of Mc Donald et al. [12] that ruminants tend to be eating more feed of lower quality in order to satisfy their need for energy and other nutrients. Another possible reason for variation in the feed intake could be as a result of individual differences in the feeding habits of the animals as reported by Payne [13] and Lynch et al. [14] that states that, individual variations among animals affect the rate of feed intake. Average daily weight gains (ADWG) of 32.22-45.89 $\mathrm{g} /$ day reported in this study was lower than (ADWG) of $90.58 \mathrm{~g} /$ day reported by Bawala et al. [15] when they replaced sugarcane tops (grass) with leucocephala (legume) foliage to West African Dwarf sheep and $94.9 \mathrm{~g} / \mathrm{d}$ reported by Ramli et al. [10] for goats fed fermented sugarcane bagasse feed. Also the values were higher than the values of $7.50-24.3 \mathrm{~g} / \mathrm{d}$ reported by Ochepo et al. [16] for complete diet containing sugarcane peels fed to West African Dwarf goats. This study agreed with the values of $52 \mathrm{~g}$ /day reported by Bounthavone et al. [17] for goats fed basal diets of sugarcane stalk. Also the average daily gain (ADWG) recorded for this experiment is comparable to what had been reported for most conventional feed ingredients. Values of average daily water intake ranged from 665.59 $838.55 \mathrm{ml} /$ day in this study and are within the values of $0.8520-1.257$ liters reported by Ochepo et al. [16] and 680 $\mathrm{ml} /$ day as reported by Devendra and Mc Leroy [18] for pen fed Katjang goat raised for meat production. Chesworth [19] reported that goat breeds which were accustomed to living in desert have only one and a half of water requirement of temperate breeds. The values of feed to gain ratio (FCR) of 7.63- 8.71 (intake/kg gain) reported by this study is lower than 11.12-28.36 reported by Ochepo et al. [16] for complete diet containing sugarcane peels fed to West African dwarf goats and 13.3 reported by Ramli et al. [10] for goats fed fermented sugarcane bagasse feed. In this study, FCR were best obtained in treatments TI (7.63) and
T3 (7.95). The lower value of feed to gain ratio in treatments $\mathrm{T} 1$ and $\mathrm{T} 3$ in this study is an indication that the diets were better utilized by animals and that the animals on the diets had better ability to convert feed to meat.

Results of the effects of feeding sugarcane peels based diets on carcass characteristics of experimental goats shown on Table 4 indicated that, the Loin and back expressed as percentage live weight were significantly $(\mathrm{p}<0.05)$ affected by the levels of cassava peel meal that was partially replaced with sugarcane peel meal inclusion. The results of the dressing percentage were generally similar to the values obtained for tropical breeds by several authors Steele [20], Devendra and Mc Leroy [18]. These results also agreed with the fact that, to a certain extent, the dressing rate increases with increasing slaughter age, feed, weight, breed and sex. Devendra and Mc Leroy [18] reported that on balance diets, most tropical sheep and goats dress out at $40-50 \%$. Since practically, all of the by products are consumed as food with some parts and organs selling at a higher price than carcass meat, dressing percentage are less importance in the tropics than in the temperate zone. Others retail cuts were not significantly affected by the dietary treatments which may imply that, the experimental diets has no ability to support performance and development of the body organs of goats.

All visceral parameters measured were not significantly affected by the levels of inclusion of the peel meals as seen on Table 5. This agreed with the study of Frandson [21] that, the non-significance of internal organs could mean that the test diets are safe for animals' consumption. The nonsignificant value of the heart specifically reported in this study agreed with the report of Frandson [21] who stated that, variation in the size of heart is a sign of abnormal blood circulation. The non-enlargement of other visceral organs such as lungs, liver, heart, kidney, spleen, testes, full gut and empty gut in this study is an indication that, the peel meals does not have any negative effect on the development of the whole cuts and is therefore safe for goats' feeding and could be incorporated as feeds ingredients for their feeding which can then be used for increasing meat production.

\section{References}

[1] Onyawoye O. O. 1998. Investing in Nigeria Future with Sheep and Goat Production. All and Charles publication Ltd pp 1618. 
[2] Nuru S. 1985. Trends in Small Ruminant Production in Nigeria. Proceeding of National Conference on Small Ruminant Production held at Zaria, Nigeria. October 6-10 1985 pp 25-49.

[3] Osori O. I. K. 1996. Seasonal Variation in Reproductive Activities of Indigenous Cattle of Northern Nigeria Ph. D Thesis ABU, Zaria. Beef Cattle production. Nat. Conf. on Beef Production Proceeding p. 226-258.

[4] Aduku A. O. 1993. Tropical feed stuff analysis table. Department of Animal Science, Faculty of Agriculture, Ahmadu Bello University, Samaru, Nigeria Pp 1-4.

[5] Ademosun A. A. 1994. Constraint and prospects of small ruminant research and development in Africa. $\mathrm{C} T$. A Publication series S. H. B and E. K. Irugum (Eds). Book of processing of Int. Cont. of the African Sm. Rum. Res. Network, Tanzania, $266 \mathrm{p}$.

[6] Sa' adullah M. 1984. Studies on utilization of rice straw by cattle. Ph. D Thesis. Royal Veterinary University, Copenhagen.

[7] Ayoade J. A., Carew S. N. and Ameh A. E. 2007. The feed value of sugarcane scrapping meal for weaner rabbits: Growth, meat yield and cost of production: Proceedings of the $3^{\text {rd }}$ annual conference of the Nigeria Society of animal production, University of Calabar March 18-21, 2007, Pp 544-546.

[8] AOAC 2006 Association of Official Analytical Chemists. Official Method of Analysis (18 ${ }^{\text {th }}$ edition) Vol. 1 Arlington, Virginia, USA.

[9] MINITAB Statistical Software, 2014. V. 16, Minitab Inc. P. A., US

[10] Ramli M. N., Higashi M., Imura Y., Takayamal K. and Nakanishi Y. 2005. Growth, feed efficiency, behaviour, carcass characteristics and meat quality of goats fed fermented Bagasse Feed. Asian-Aust. J. Anim. Sci. 2005. Vol. 18, No. 11: 1594-1599.

[11] Salah G 2010 Utilization of sugarcane peels by Yankasa Lambs in Savannah Zone. M. Sc. Dissertation, Department of Animal Science, Bayero University, Kano.
[12] Mc Donald P., Edward R. A., Greenhalgh J. F. D. and Morgan C. A. 1995. Animal Nutrition ( $5^{\text {th }}$ ed.), Longman, London.

[13] Payne W J A 1990 An Introduction to Animal Husbandry in the Tropics: (4 ${ }^{\text {th }}$ Edition). Longman Singapore Publishers. Pp. 67.

[14] Lynch J J, Hinch G N, and Adams D B 1992 The Behaviours of Sheep. Biological Principles and Implication for production, C. A. B. International Wallington Oxen.

[15] Bawala T. O., Onwuka C. F. L., Oni A. O., Adebisi Y. and Alli M. A. 2008. Studies on performance of sheep fed sugarcane saccharum officinarum tops supplemented with varying level of Leucacna Leucocephala Foliage: Proceeding of Animal Production, Ayetoro, Nigeria, pp 575-578

[16] Ochepo C. O., Ochepo G. O. and Ayoade J. A. 2012. The utilization of complete diet containing sugarcane peels by goats. In: Proceedings of the $37^{\text {th }}$ annual conference of the Nigerian Society for animal production, University of Agriculture, Makurdi, March 18-21, 2012, pp. 507-511.

[17] Bounthavone K., Vanthong P. and Preston T. R. 2008. Effects of fresher sun-dried cassava foliage on growth performance of goats fed basal diets of Gamba grass or sugarcane stalk. National Agriculture and Forestry Research Institute Ministry of Agriculture and Forestry, P. O. Box 811, Vientiane Laos Finca Ecologica, UTA-Colombia, AA\#48, Socorro, Santander, Colombia ISBN 978-91-86197-19-9.

[18] Devendra C. and Mc Leroy 1982. Sheep and Goat Production in the Tropics. Longman Scientific Group Ltd. UK. 8-17.

[19] Chesworth J 2002 Ruminant Nutrition: The Agriculturalist: Published in co-operation with the Technical Centre for Agriculture and Rural Co-operation, Wageningen, The Netherlands.

[20] Steele M. 1996. Nutrient and Feeding in Goats Hong Kong. Pp. 22-36.

[21] Frandson R. D. 1981. Anatomy and Physiology of Farm Animals. $3^{\text {rd }}$ Edition. Bialiare Tindall Publishers, London. Pp 62-94. 